\title{
PRAHA ARCHEOLOGICKÁ. KONCEPCE A REALIZACE PROJEKTU INTEGROVANÉHO INFORMAČNÍHO SYSTÉMU ARCHEOLOGICKÝCH PRAMENŮ PRAHY
}

\author{
IVANA BOHÁČOVÁ - JAROSLAV PODLISKA
}

\begin{abstract}
Abstrakt: V roce 2013 byl zahájen pětiletý projekt Archeologického ústavu AV ČR, Praha, v. v. i., a Národního památkového ústavu, územního odborného pracoviště v hl.m. Praze, v rámci Programu aplikovaného výzkumu a vývoje národní a kulturní identity (NAKI). Projekt s názvem Integrovaný informační systém archeologických pramenů Prahy (IIS_APP) si klade za cíl vytvořit v prostředi GIS interaktivní geograficko-informační systém vycházející z Mapy archeologických dokumentačních bodỉ, kterou od roku 1975 vytvářel v Archeologickém ústavu v Praze PhDr. Ladislav Hrdlička. Jde o speciální nástroj určený pro historické jádro Prahy - městskou památkovou rezervaci a památku UNESCO, který má umožnit hospodárné nakládání s jeho výjimečným archeologickým fondem, a to jak v oblasti jeho védeckého zhodnocování, tak v oblasti památkové péče. Prostřednictvím webového portálu budou informace prístupné on-line nejen odborníkưm a pracovníkưm veřejné správy, ale i široké veřejnosti. Systém je stavěn jako obecný a lze jej využit pro kteroukoliv zkoumanou lokalitu v ČR. Cílem projektu je 1 - vytvoŕit interaktivní informační systém archeologických pramenů Prahy (IIS_APP) v prostředi GIS. Jeho prostřednictvím pak zajistit 2 - hospodárné nakládáni s archeologickým fondem evropského významu a jeho využivání pro základní výzkum, památkovou péči, státni správu, územní rozvoj a plánování i pro prezentaci kulturního dèdictví, 3 -jednoznačné propojení dat ve stávajicich a obecněji zaměřených evidenčních a databázových systémech různých typů, obsahů a funkcí, 4 - průběžnou on-line aktualizaci a revizi údajů o archeologických výzkumech na území historického centra Prahy a nových pramenech k archeologii Prahy obecně, 5 - běžnou dostupnost širšího spektra dat a typů dokumentů a 6 -vytvořit obecně využitelný strukturovaný systém vyvinutý v prostředí GIS pro evidenci, využití a prezentaci specifického typu archeologických pramenů, a to jako speciální vrstvy Archeologické mapy $\check{C} R$.
\end{abstract}

Klíčová slova: archeologie - GIS - kulturní dědictví-město - Praha.

Prague - The City of Archaeology. The concept and realisation of the project of an integrated information system of Prague's archaeological sources

\begin{abstract}
In 2013 the Institute of Archaeology of the Academy of Sciences of the Czech Republic, Prague, v. v. i., and the National Heritage Institute, Prague launched a five-year project within the Programme of Applied Research and Development of the National and Cultural Identity (NAKI). The main objective of the project, entitled the Integrated Information System of Prague's Archaeological Sources (IIS_APP), is to create in the GIS environment an interactive geographic information system based on the Map of Archaeological Documentation Points, the work on which was started by PhDr. Ladislav Hrdlicka at the Institute of Archaeology in Prague in 1975. The map is a specialized tool designed for the historical centre of Prague, a UNESCO-listed urban heritage reserve, that will enable a considerate employment of its unique archaeological heritage, both in the area of its scientific assessment and protection. The information will be made available online through a website, not only for specialists and those working in the public administration but also for the general public. The system is designed as a general one and can be applied to any investigated location in the Czech Republic. The project's objectives are as follows: 1 -creation of an integrated information system of Prague's archaeological sources (IIS_APP) in the GIS environment, ensuring; 2 - considerate employment of the city's unique archaeological heritage of European importance and its application in basic research, heritage care, public administration and urbanism, as well as in the presentation of cultural heritage; 3 - combining data from the existing and more general register and database systems of different types, contents and functions; 4 - continuous online updating and revision of data about archaeological research in the historical centre of Prague and new sources for the archaeology of the city in general; 5 - access to a broad spectrum of data and document types; 6 -creation of a universally valid structured system in the GIS environment for the cataloguing, application and presentation of a specific type of archaeological sources, as a special layer of the Archaeological Map of the CR.
\end{abstract}

Key words: archaeology - GIS-cultural heritage-city-Prague. 


\section{Východiska projektu}

V roce 2012 byl Ministerstvem kultury ČR v rámci programu NAKI (Program aplikovaného výzkumu a vývoje národní a kulturní identity) podpořen pětiletý projekt, jehož základním cílem je zpř́stupnění informací o archeologických pramenech z historického jádra pražské sídelní aglomerace odborné i nejširší veřejnosti (reg. č. DF13P01OVV014, 2013-2017). Hlavním př́ijemcem podpory a řešitelem se stal Archeologický ústav AV ČR, Praha, v. v. i, ve spolupráci s pražským pracovištěm Národního památkového ústavu.

Důvodů $\mathrm{k}$ formulaci tohoto projektu byla celá řada. Základním impulzem byl neutěšený stav zpracování a zpř́stupnění bohatého archeologického fondu, který je z historického jádra Prahy získáván více či méně systematicky již téměř jedno století. Druhým závažným důvodem byla absence aktuálních - tedy průběžně aktualizovaných - informací o rozsahu in situ dochovaného archeologického fondu Prahy, přesněji řečeno absence efektivní možnosti aktualizovat $\mathrm{v}$ měřítku přiměřeném historickému jádru města (tj. $\mathrm{v}$ měřítku katastrální mapy) informace o zásazích do historických terénů. Tyto informace jsou nezbytné jak z hlediska ochrany archeologických památek, tak z hlediska potřeb kvalifikované př́ípravy potenciálního záchranného výzkumu. Třetím klíčovým impulzem byl pak razantní nástup interdisciplinárního studia a rozvoj moderních technologií a zejména skutečnost, že jejich adekvátní využití, at' již pro dokumentaci, nebo pro interpretaci archeologických pramenů není možné bez systematické evidence realizovaných analýz a jejich výsledků. Její vybudování je sice obecným problémem, ale v měřítku Prahy je alespoň možné efektivně přispět k jeho řešení.

Počátky systematického archeologického výzkumu Prahy, a tedy i tvorby unikátního archeologického fondu lze spojovat s působením Památkového sboruhl.m. Prahy. Ten v rámci Magistrátu hl. města Prahy od počátku 20. let inicioval a do značné míry i organizoval, s péčí do té doby nebývalou, výzkumy či alespoň archeologický dohled při stavebních aktivitách v historickém jádru Prahy, a to včetně zř́izení meziinstitucionálních komisí pro výzkum Pražského hradu a Vyšehradu (Boháčová v tisku a). K dalšímu nárůstu výzkumů vyvolaných stavebními aktivitami došlo na přelomu 60. a 70. let především v souvislosti s budováním městské infrastruktury, obzvláště se stavbou metra a nových obchodních a kancelářských objektů (RichterSmetánka 1965; Richter 1984; Podliska-Tryml 2012, 101-102). Intenzita a rozsah záchranných archeologických výzkumů nabíraly na intenzitě v posledních dvou desetiletích 20 . a dospěly pak ke svému vrcholu na počátku 21. století. Dluh ve vyhodnocování získaných pramenů dodnes soustavně narůstá. Svůj podíl na tom má často nebývalý objem stavebních prací a četnost stavebních zásahů v historickém jádru a nověji i mimo něj. Starší výzkumy přitom zůstávají dlouhodobě nevyhodnoceny a s větším časovým odstupem nutně a z mnoha důvodů klesá nejen pravděpodobnost jejich budoucího zpracování, ale i výpovědní hodnota pramenů, které byly shromážděny. Vyhodnocování archeologických pramenů a posun v poznání nejstarší historie Prahy tak nutně zaostává za možnostmi, které mimořádný fond pražských nálezů poskytuje, a stává se, zejména pohlížíme-li na historické jádro Prahy jako na celek, zcela neefektivním procesem. Krom toho archeologické prameny díky rozvoji rozmanitých vědních disciplín vstupují do interdisciplinárního studia jako jeho samozřejmá a zcela nezpochybnitelná součást $\mathrm{s}$ dosud jen málo vyčerpaným potenciálem. Díky tomu nejen finanční, ale i časová náročnost archeologického výzkumu ve všech jeho fázích včetně zpracování nadále stoupá.

Bez aktuálních a systémově evidovaných informací o stavu archeologických terénů a jejich hodnotě je jen obtížně možné odůvodněně a systematicky chránit alespoň nejcennější části výjimečného podzemního fondu. S nárůstem počtu institucí podílejících se na záchranných výzkumech se problematickou stala nejen koordinace výzkumů, ale i vzájemná informovanost odborné veřejnosti o realizovaných výzkumech na území Prahy, jejich rozsahu i výsledcích. Přitom úspěšná volba metodiky i efektivní metody výzkumů je v tak složitém organismu, jakým je historické jádro Prahy, jednoznačně závislá právě na znalosti jak širšího kontextu, tak konkrétních podmínek naleziště. 
Ve své snaze o systémové zpř́istupnění archeologických pramenů odborné veřejnosti může současná pražská archeologie navázat v podstatných momentech na úsilí badatelů předchozích generací. Z hlediska metodického byla inspiračním východiskem uvedeného projektu především práce dvou archeologů středověku - M. Richtera a L. Hrdličky. Podmínky pro realizaci konceptu úzké spolupráce mezi institucemi, zajišt’ujícími záchranný výzkum a jeho vyhodnocení výkonem archeologické památkové péče i průzkumem památek, byly v pražských podmínkách budovány od poloviny 60 . let. Vznikem odborné Komise pro archeologický výzkum Velké Prahy (1969), později transformované na koordinační orgán pražské archeologie tzv. Pražskou archeologickou komisi (PAK, od roku 1978), byla vytvořena regionální platforma, která s určitými přestávkami plní svůj úkol dodnes. O koncepci koordinace činnosti jednotlivých institucí a garance odborné úrovně výstupů, a to v rámci celého výzkumného procesu od formulace otázek výzkumu až po vznik nálezových zpráv se zasazoval především $\mathrm{M}$. Richter (tehdy v pozici ředitele Archeologického ústavu ČSAV; Richter 1984). Klíčovou osobou z hlediska rozvoje metodiky „strategie a taktiky“ záchranného výzkumu se posléze stal L. Hrdlička, který pozvedl evidenci pražských záchranných výzkumů, vznikající v rámci PAK, z úrovně prostých administrativních záznamů do úrovně jednoznačně definovaného nástroje (Hrdlička 2005; 2009), využitelného a zejména nepostradatelného pro sledování badatelských témat alespoň v prostoru jádra pražské sídelní aglomerace - na území Pražské památkové rezervace.

Inspiraci v minulosti lze nalézt i pro oblast popularizace výsledků archeologického snažení. K činnostem, jimiž se zabýval Památkový sborhl.m. Prahy a které doposud zmíněny nebyly, náleží i dnes intenzivně pocitovaná potřeba prezentace výsledků archeologického bádání nejširší veřejnosti. Nešlo pouze o publikační výstupy, které ovšem tehdy - mimo jiné i vlivem válečných událostí - zůstaly nenaplněny, ale i o přednáškové aktivity a zejména o tehdy nový a po vzniku Československé republiky atraktivní fenomén prezentace významných nemovitých archeologických nálezů in situ. Tato forma přiblížení archeologických památek bude představena v detailu na jiném místě (Boháčová v tisku b), ale i ona náleží k jednomu z inspiračních zdrojů formulovaného projektu.

Pokud jde o interdisciplinární výzkum, Praha náleží k lokalitám, na nichž byl v některých svých tématech rozvíjen poměrně záhy, systematicky pak zvláště od 80 . let 20. století. Po prvých izolovaných analýzách archeobotanických makrozbytků, zvláště v 60. letech (prvá analýza na svahu hradčanského ostrohu byla realizována dokonce již v r. 1940), byl např. v rámci projektu Počátky Prahy (GAČR, L. Hrdlička 1994-1996, reg. č. 404/94/100) započat systematický sběr vzorků pro pylové analýzy z výzkumu jádra pražského levobřeží. K publikaci výsledků, které neměly statistickou průkaznost (at' již vzhledem k složité genezi zkoumaných stratigrafí́, nebo někdy malému rozsahu situací, a také ne vždy příhodným podmínkám pro uchování pylů), však nedošlo. Cenné poznatky byly získány souběžným makrozbytkovým a palynologickým studiem vzorků odebíraných z nejstarších kulturních horizontů raně středověké Prahy a provázáním jejich výsledků (Kozáková-Boháčová 2008; Čulíková v tisku). Mimořádný význam, překračující hranice Prahy i středních Čech, mělo vybudování dendrochronologického standardu dubu pro Českou republiku. Základem pro konstrukci křivky byly raně stř̌edověké konstrukce z pražského levobřeží (Dvorská-Boháčová 1999). S přibývající četností nálezů pyrotechnologických zařízení se rozvinulo systematické studium technologie výroby a zpracování kovů (HavrdaPodliska-Zavřel 2001; Podliska 2014). Značná pozornost je v rámci Prahy věnována geomorfologickým procesům, surovinám a jejich zdrojům. Pro pražskou archeologii je od počátku jejího rozvoje typická těsná kooperace s odborníky s příslušným oborovým vzděláním. Tato spolupráce měla vždy bezprostřední vliv na rozvoj metodiky výzkumu, v několika př́ípadech geologové posílili řady pražských terénních archeologů a dnes jsou odborníci s různou specializací z oboru geologie běžnými členy výzkumných týmů. S výčtem disciplín mezioborového studia není při intenzitě jeho rozvoje třeba dále pokračovat, nebot' by byl vzápětí antikvován. Pro městské prostředí připomeňme snad alespoň v Praze tradiční kooperaci se stavebními historiky a nezbytnou, i když zatím ne zcela standardně dostupnou spolupráci s odborníky zabývajícími se interpretací městských archiválií. 
Přestože archeologické prameny z pražských výzkumů jsou dnes již standardně využívány ke studiu rozmanitých témat mezioborového výzkumu, neexistuje systematická evidence realizovaných analýz a přehled analyzovaných pramenů. Většina výsledků není publikována, některé analýzy čekají na další využití v šuplících autorů výzkumů, či dokonce autorů těchto analýz. Nelze je tak využit v rámci oboru jako celku, často jsou založeny pouze na osobních kontaktech badatelů. Základní evidence analýz a analyzovaných vzorků, at' již z archeologických, či jiných aktivit, jejíž vybudování je jedním z dílčích cílů projektu, by měla umožnit intenzivnější rozvoj, a tedy i posun poznání ve všech dotčených oblastech. Do úrovně jednotlivých vzorků by měla být např. budována zatím neexistující databáze chronometrických údajů (dendrodata, ${ }_{14} \mathrm{C}$ ). $\mathrm{Bez}$ dostupné evidence a zpř́stupnění získaných poznatků jsou tyto cenné prameny pro další studium nevyužitelné, a tak v podstatě znehodnocené.

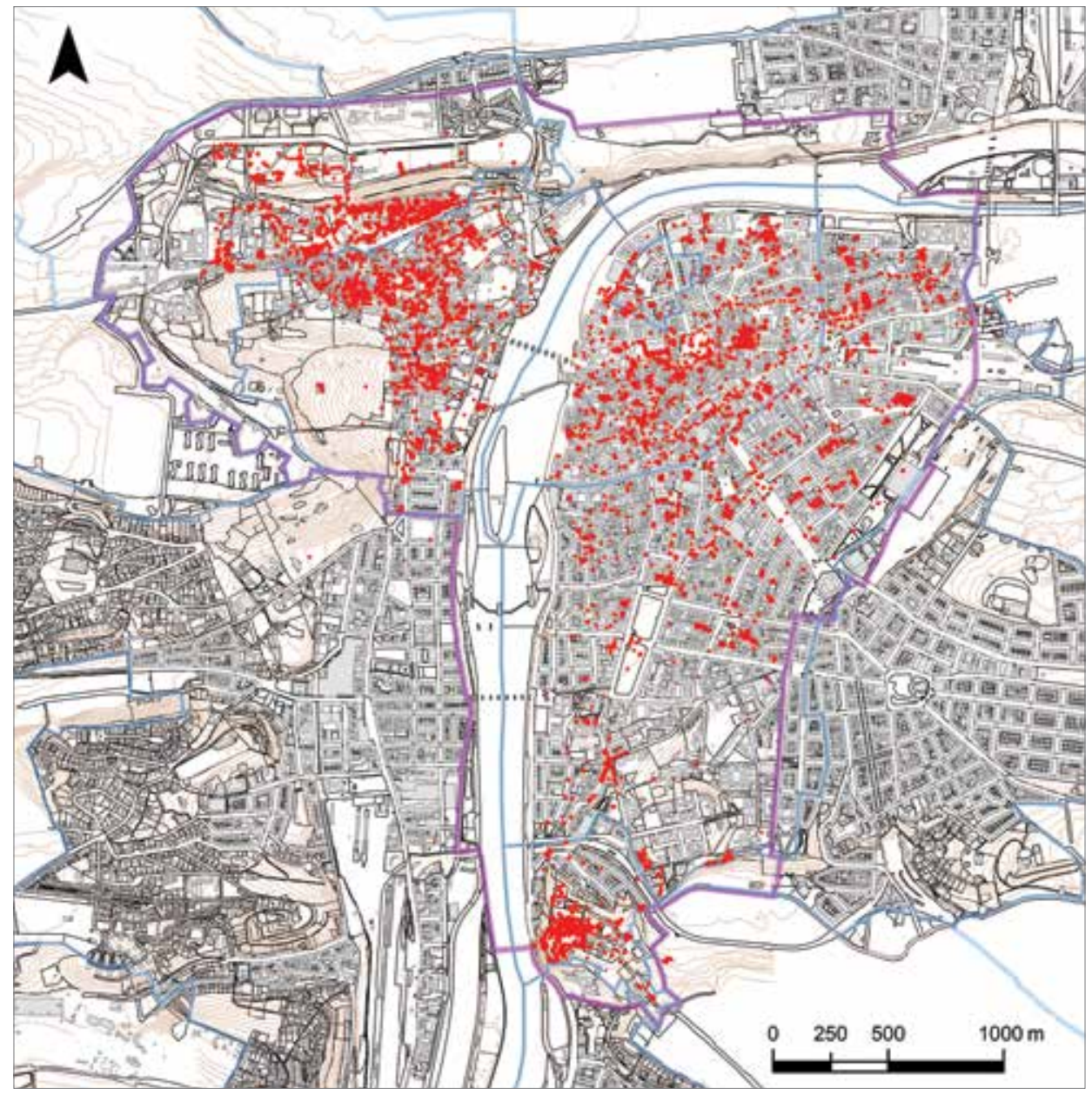

Obr. 1. Plošný rozsah záznamů mapy archeologických dokumentačních bodů - tzv. Hrdličkovy mapy (MADB). Základem pro evidenci byly listy ZM 1:1 000, číslování sond pak běželo ve třech nezávislých řadách, a to podle kladu listů ZM 1:5 000 (list 6-1,7-1 a 7-2). Detailně viz Hrdlička 2005. Styl zobrazení 1:10 000. Datový podklad (digitální katastrální mapa Prahy) @ Institut plánování a rozvoje hl. m. Prahy.

Abb. 1. Flächenmäßige Ausdehnung der Eintragungen in der Karte der archäologischen Dokumentationspunkte - sog. Hrdlička-Karte (MADB). Als Vorlage zur Erfassung dienten Blätter der Grundkarte 1:1 000, die Nummerierung der Sondagegrabungen erfolgte dann in drei unabhängigen Reihen, und zwar nach dem Blattschnitt der Grundkarte 1:5 000 (Blatt 6-1,7-1 und 7-2). Im Detail siehe Hrdlička 2005. Darstellungsstil 1:10 000. Datenunterlage (digitale Katasterkarte von Prag) @ Institut für Planung und Entwicklung der Hauptstadt Prag. 


\section{Historie mapy archeologických dokumentačních bodů na území Pražské památkové rezervace}

Mapa archeologických dokumentačních bodů, tzv. Hrdličkova mapa, respektive databázové záznamy této mapy se staly základním pilířem nově budovaného systému. Počátky projektu mapy lze hledat již v 70. letech, kdy L. Hrdlička započal v souvislosti s rekonstrukcí georeliéfu historického jádra Prahy s evidencí základních a autorským právem nechráněných informací z výzkumů v jádru pražské aglomerace (obr. 1). Data o realizovaných archeologických akcích byla shromažd’ována v dostupných databázových systémech, dlouhodobě jako soubor dbase IV. Popisné údaje a komentář ke koncepci a sestavení mapy obsahovala pak textová část publikace (Hrdlička 2005), provázená ukázkou mapy (výsek pražského levobřeží z listu 7_1) a posléze aktualizovaná vydáním v elektronické podobě (Hrdlička 2009). Evidovány byly nejen archeologické dokumentační body (ADB) s přesným prostorovým zaměřením, ale i takové, jejichž umístění bylo jen orientační např. ve vztahu k pozemkové parcele. Jako zvláštní srovnávací kategorie byly zahrnuty i některé geologicky dokumentované body. Vedle databáze evidující tyto informace vznikala fyzicky mapa archeologických dokumentačních bodů (MADB), respektive mapa archeologických zásahů různých typů (bod, linie, plocha), jejíž optimální podobu představovala v tehdejších podmínkách kombinace základních listů katastrální mapy 1:1 $000 \mathrm{~s}$ astralonovými fóliemi (obr. 2), na nichž bylo možno s přiměřenou mírou přesnosti zaznamenávat konkrétní

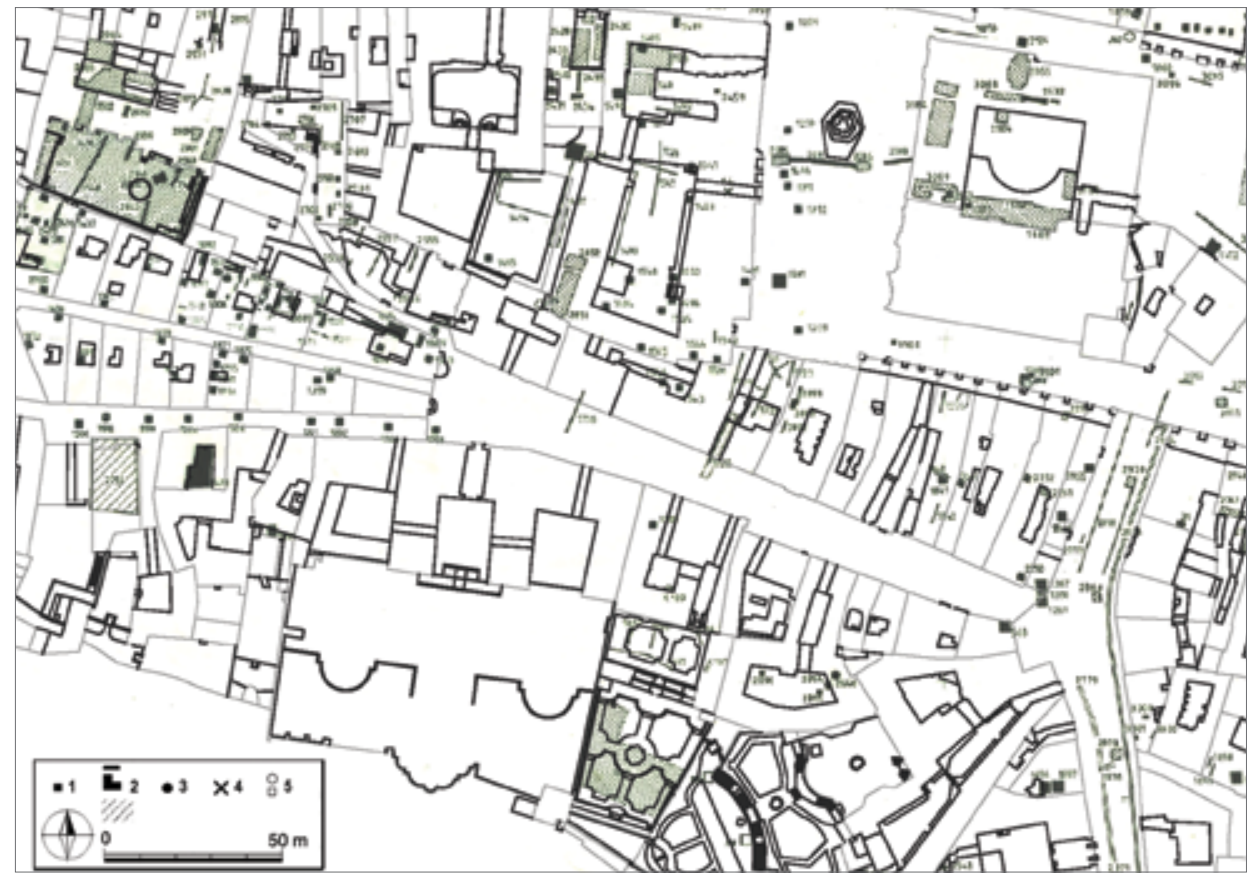

Obr. 2. Snímek astralonového listu 242 MADB (výřez) podloženého katastrální mapou Prahy 1:1 000. Pozůstalost L. Hrdličky, archiv nálezových zpráv ARÚ AV ČR, Praha, v. v. i. Převod do elektronické podoby R. Vlčková.

Abb. 2. Aufnahme von Astralonblatt 242 MADB (Ausschnitt) der zugrundegelegten Katasterkarte von Prag 1:1 000. Nachlass L. Hrdlička, Archiv der Befundberichte des Archäologischen Instituts der Akademie der Wissenschaften der Tschechischen Republik, Prag. Übertragung in elektronische Form R. Vlčková.

sondy v jejich reálné ploše či linii (pro sondy s rozměrem pod dva metry pak bodově) a průběžně tyto záznamy aktualizovat. Oproti tehdy obecně používanému systému bodové evidence archeologických akcí na základních mapách (ZM) 1:10 000 byl tento systém z hlediska městského intravilánu jednoznačnou inovací, využitelnou jak pro potřeby řešení badatelských témat, tak 
při projektování dalších archeologických aktivit. Současně se stal nezastupitelnou oporou pro zdůvodňování nezbytné míry ochrany archeologických terénů i možnou pomůckou pro investory při rozhodování o konkrétních stavebních záměrech. Impulzem pro vznik Hrdličkovy mapy byly nesporně možnosti, které poskytly - jak pro oblast ochrany archeologických památek, tak pro projektování badatelských aktivit a vyhodnocování získaných pramenů - informace soustřed’ované v rámci PAK. Maximální úsilí, které L. Hrdlička tvorbě databáze a její mapové podobě věnoval, souviselo i s jeho schopností předvídat nárůst možného ohrožení archeologických pramenů, a to nejen v jejich primární podobě pod dlažbou či v rámci historických konstrukcí v souvislosti $\mathrm{s}$ očekávaným rozvojem stavebních aktivit $\mathrm{v}$ historickém jádru Prahy, ale i v podobě nálezů, vzorků, které již byly vyzvednuty a přemístěny do pracoven či laboratoří, nebo ve formě dokumentace vyčkávaly svého zhodnocení. Př́ikladů, při nichž došlo k nevratným ztrátám působením dějinných či živelných událostí nebo lidského faktoru, není málo (krom požáru a zániku dokumentace pražského památkového fondu ve Staroměstské radnici v roce 1945 připomeňme povodeň, která postihla pražský Archeologický ústav v r. 2002) a hrozba dalších možných katastrof se s nárůstem nezpracovaného fondu samozřejmě stále zvyšuje.

Fyzická podoba mapy vznikala ve dvou paré, v závěrečné fázi její tvorby však bylo aktualizováno již jen jedno z nich. Stavební boom v historickém jádru Prahy od poloviny 80. let a další rozmach stavebních aktivit v 90 . letech 20 . století i na počátku století následujícího ukázal neudržitelnost původního konceptu fyzické podoby mapy. Shromažd’ování údajů v nové situaci se stávalo stále obtížnějším. Důvodů byla celá řada, vedle zvyšujícího se počtu akcí také jejich kumulace na malém prostoru, změny v organizaci archeologické památkové péče, omezené kapacity pražské archeologie nebo i nedisciplinovanost některých kolegů. Dluhem nadále zůstávaly některé výzkumy z nejstarší - prvorepublikové éry pražské archeologie, protože jejich prostorové vymezení není známé a $\mathrm{v}$ některých př́ípadech nemusí být již rekonstruovatelné.

Přes maximální úsilí vynakládané L. Hrdličkou bylo zřejmé, že daný úkol je nad možnosti jedince a že zcela nezbytná je inovace původního systému prostorové evidence zásahů. Nástup nových technologií současně přinášel nová možná řešení. Rozvoj GIS vedl k opakovaným pokusům převést existující prostorové údaje do jejich prostř̌edí. Prvý převod prostorových dat, realizovaný P. Starcem v Muzeuhl. města Prahy (2008-2009), vycházel z fyzické podoby mapy (obr. 3), zůstal však nedokončen, respektive nebyl již aktualizován dle revidované podoby mapy (Hrdlička 2009). Protože MADB byla od počátku progresivně postavena nejen na zobrazení konkrétních zkoumaných poloh na fyzickém podkladu, ale i na záznamu obecně využitelných souřadnicových údajů, vztáhnutelných ke konkrétnímu mapovému listu, bylo možné předpokládat snazší převod dat do automatizovaného systému geografických informací. Současně byl položen základ pro budoucí efektivní revizi mapového zobrazení. Druhý převod prostorových dat, realizovaný již v rámci ARÚ, byl postaven právě na reálných datech převedených z formátu DB IV. V roce 2008 byl zajištěním tvorby mapových podkladů, které by umožnily průběžnou centrální aktualizaci dat, pověřen oficiálně vedením ARÚ tým jeho pracovníků. Byl vytvořen systém propojující sběr dat pro oborový archiv (systém Archiv 3) s doplňováním databáze ADB, prostorová data byla vložena do prostředí GIS GeoMédia Registred Research Laboratory INTERGRAPH, USA. Ani tento systém se však neukázal jako funkční, nebot' vkládání nových dat, nehledě na potřebu revize starších údajů, nebyl tento tým schopen z kapacitních důvodů zajistit, přestože měl i určitou institucionální podporu. Běžně dostupnou, a tedy snadno využitelnou a aktualizovatelnou grafickou podobu mapy se tak L. Hrdličkovi již dokončit nepodařilo ani v rámci tohoto širšího pracovního kolektivu.

\section{Praha archeologická - projekt Integrovaného informačního systému archeologických pramenů Prahy (IIS_APP) a jeho koncepce}

V roce 2013 byly zahájeny práce na projektu IIS_APP, jehož východiskem a základní informační rovinou je mapa archeologických dokumentačních bodů na území Pražské památkové rezervace (MADB, neoficiálně Hrdličkova mapa). Projekt byl formulován na půdě Archeologic- 
kého ústavu AV ČR, Praha, v. v. i., jeho řešení však není myslitelné bez úzké spolupráce s pracovníky odboru archeologie Národního památkového ústavu, ú. o. p. v hl.m. Praze, a dalšími externími spolupracovníky působícími v pražské archeologii.

Výjimečnost a určité prvenství pražské tzv. Hrdličkovy mapy je především v komplexním pohledu jejího autora na problematiku pražské archeologie jako na ucelený systém informací, bez něhož nejenže nelze zajistit ochranu archeologických pramenů, ale který je především zcela neopominutelným předpokladem pro kvalifikovanou volbu metody výzkumu zanikajících situací a pro formulace témat adekvátních zkoumanému prostředí a jeho širšímu kontextu, zejména však pro kvalifikované a v možné míře systematické vyhodnocování získaných pramenů.

Východiskem pro vytvoření MADB v prostředí IIS_APP bylo rozhodnutí, že základní koncepce původního projektu L. Hrdličky bude v maximální možné míře respektována. Shodně jsou pojaty základní typy sond (bod, linie, plocha) a přesnost jejich lokalizace. Otázka evidence třetího - tedy vertikálního - rozměru, která měla v původním projektu zřejmé slabiny vzhledem k možnému subjektivnímu přístupu k evidovaným hodnotám, byla dořešena zavedením kategorie výškových referenčních bodů. Ty umožňují evidovat jak rozpětí základních kulturních horizontů (v detailu závislém na subjektivním rozhodnutí autora výzkumu), tak jejich přesné prostorové umístění.

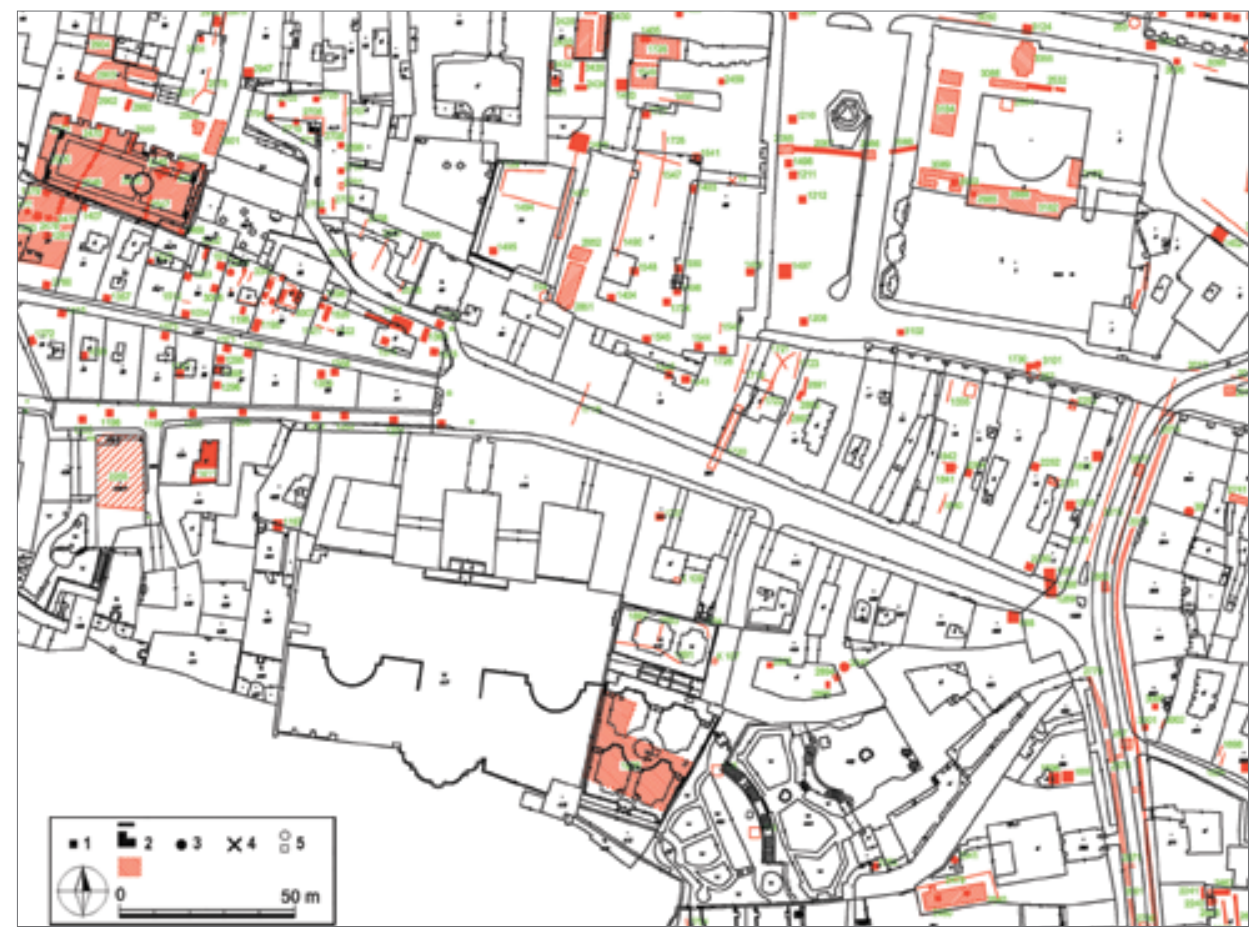

Obr. 3. Zobrazení prostorových dat MADB podle P. Starce (2009). Snímek z listu 242 (výřez).

Abb. 3. Darstellung der Raumdaten der MADB nach P. Starec (2009). Aufnahme von Blatt 242 (Ausschnitt).

\section{Koncepce IIS_APP je postavena na těchto tezích:}

1 - Základním cílem projektu je vybudování geograficko-informačního systému určeného k on-line aktualizaci informací o archeologických pramenech Prahy a k zveřejnění těchto informací prostřednictvím internetu.

2 - IIS_APP je chápán jako obecně využitelný ucelený systém informací umožňující na základě znalosti širších souvislostí volbu přiměřené metody výzkumu, kvalifikované oborové 
i mezioborové vyhodnocování archeologických pramenů v intravilánech historických sídel, hospodárné nakládání s těmito prameny a jejich kvalifikovanou a systematickou ochranu.

3 - IIS_APP je cílen na všechny potenciální uživatelské skupiny - tj. odbornou veřejnost (základní výzkum včetně interdisciplinárních témat, památková péče), orgány státní správy a místní samosprávy i nejširší veřejnost. Jednotlivým skupinám uživatelů jsou přizpůsobeny základní sekce webového prohlížeče.

4 - Východiskem IIS_APP je tzv. Hrdličkova mapa-Mapa archeologických dokumentačních bodů na území Pražské památkové rezervace, přičemž je v základech respektována původní metodika její tvorby.

5 - IIS_APP je budován jako jedna z vrstev nadřazeného informačního systému Archeologická mapa České republiky (AMČR). Systémové propojení s jejími daty, tj. přímé zakomponování informací shromaždovaných v jeho rámci do struktury AMČR, umožní vstup autorizovaných odborných dat do IIS_APP a využívání dalších oborových databází ARÚ (bibliografická databáze, databáze dokumentů).

6 - IIS_APP předpokládá využívání relevantních aktuálně dostupných mapových, datových i dalších podkladů vztahujících se $\mathrm{k}$ historii Prahy či k otázkám ochrany památek (především wfs, wms) vytvářených v řešitelských institucích projektu (ARÚ Praha a NPÚ) i mimo ně v rámci meziinstitucionální spolupráce či obecně zpř́istupněných pro on-line využití (IPR MHMP, MMP, Archiv HMP, HÚ AV ČR, ČÚZK aj.).

\section{Praha archeologická - realizace projektu IIS_APP}

Realizace projektu je postavena na profesních zkušenostech a úzké kooperaci dvou největších pracovišt' v ČR zaměřených mimo jiné jak na základní výzkum, tak na archeologickou památkovou péči. Projekt současně tuto spolupráci rozvíjí a prohlubuje v celém spektru jejich činností.

Projektový tým zahrnuje kromě archeologů specializovaných na základní výzkum, památkovou péči i muzejní sféru odborníky pro oblasti geologie, stavebně historických analýz, archeobotaniky i databázových systémů a GIS. Realizace projektu by samozřejmě nebyla možná bez spolupráce s řadovými technickými pracovníky a dodavatelem technického řešení systému, společností SmartGis. Postupnou realizaci projektu, detailní informace o něm a zejména naplňování systému daty bude možné sledovat od spuštění zkušební verze systému on-line na prezentačním webu na adrese www.praha-archeologicka.cz a www.praha-archeologicka.eu (obr. 4). Projekt IIS_APP je tvořen dvěma částmi. Prvá z nich (informační systém, produkt společnosti SmartGis) je speciálním nástrojem umožňujícím autorům výzkumů v př́ímé vazbě na nově vznikající AMČR, ovšem ve větší míře detailnosti prostorového vymezení a mapového zobrazení (vynesením přesného rozsahu zkoumané plochy v měřítku katastrální mapy, tj. s maximální odchylkou 100-200 cm), on-line aktualizaci dat o archeologických akcích a vkládání odkazů na př́íslušné dokumenty. Propojení MADB s AMČR je založeno na identifikaci a detailní revizi dosud v rámci obou systémů nezávisle evidovaných archeologických akcí. Revizí existujících záznamů o výzkumech jsou přitom pověřeny právě ty instituce, které tyto konkrétní výzkumy zajištovaly. Druhá část systému je webová stránka umožňující v prostředí GIS i mimo něj prohlížení veřejně př́stupných dat shromážděných nebo vytvořených v rámci IIS_APP, obrazové či jiné dokumentace, výběr dat či jejich filtrování, pověřeným specialistům (vesměs autorům výzkumů či analýz různých typů) pak vkládání a editaci prezentací či další doplňující dokumentace nebo odkazů na ně. Vybrané prezentace budou mít formu elektronické publikace, což je jedna z uznávaných standardních odborných publikací.

Webová stránka umožňuje uživateli prohlížet data pěti základních sekcí systému (obr. 5, 6, 7; mapové zobrazení homepage se mění s přechodem na jinou sekci): 1 - zkoumané plochy, 2 - Praha archeologická, 3 - za archeologií v Praze, 4 - interdisciplinae a 5 - památková péče ve formátech mapového nebo datového zobrazení. Podsekce systému (viz níže obsah jednotlivých sekcí) tvoří vertikální menu stránky, filtrovat data bude možné pouze $\mathrm{v}$ jedné $\mathrm{z}$ nich, zobrazovat 


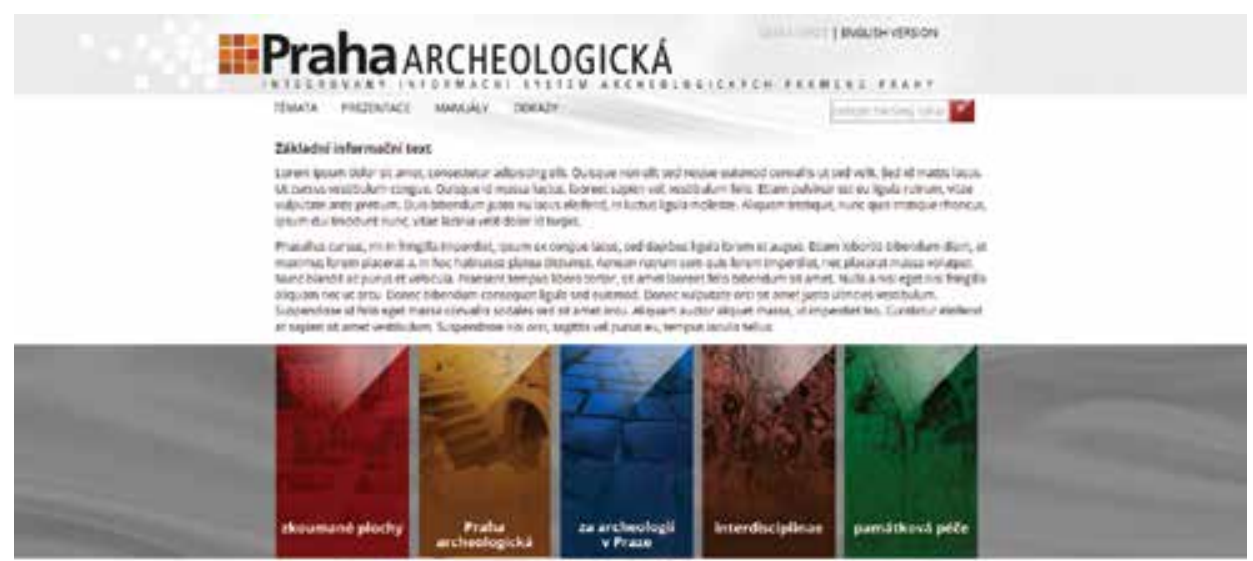

Obr. 4. Homepage projektu. U vybraných témat a prezentací se počítá s anglickou jazykovou mutací webových stránek. Prvá sekce je aktualizovanou mapou dokumentačních archeologických bodủ (MADB), poslední sekce prezentuje data vytvářená v NPÚ. Ostatní sekce jsou určeny k prezentaci dat, vytvářených postupně v rámci projektu. Stránka prezentací je platformou, na níž lze jak vážným zájemcům, tak širší veřejnosti představit konkrétní výsledky pražské archeologie a interdisciplinárního výzkumu, zajímavé projekty i nálezy.

Abb. 4. Homepage des Projekts. Bei ausgewählten Themen und für die Präsentationen ist eine englischsprachige Version der Webseiten vorgesehen. Der erste Teil ist eine aktualisierte Karte der archäologischen Dokumentationspunkte (MADB), der letzte Teil präsentiert die im Nationalinstitut für Denkmalpflege generierten Daten. Die übrigen Teile sind zur Präsentation von Daten bestimmt, die nach und nach im Rahmen des Projekts generiert werden. Die Seite Präsentation ist eine Plattform, auf welcher sowohl ernsthaft Interessierten, als auch der breiten Öffentlichkeit die konkreten Ergebnisse der Prager Archäologie und der interdisziplinären Untersuchung, interessante Projekte und Befunde vorgestellt werden können.

však systém dovolí data libovolných dalších sekcí (obr. 8). Horizontální menu webu umožní přepínání mezi mapovým a datovým zobrazením informací, vstup na stránku prezentací včetně základních informací o projektu, vstup do navazujících infosystémů, dále bude obsahovat příručky (manuál, výkladový slovník, hesláře) a základní nástroje webu.

Sekce zkoumané plochy (datová tř́ída 1 - ADB) obsahuje revidované a dále aktualizovatelné zobrazení archeologických zásahů na území Pražské památkové rezervace a jejich průvodních dat vycházející především z původní Hrdličkovy MADB. Její revidovaná data vstoupí do systému dávkově, dále budou doplňována prostřednictvím nástroje IS AMČR. Sekce Praha archeologická je sekcí zaměřenou na prezentaci vlastních archeologických pramenů a je nezávislá na datech MADB. Její součástí bude kromě prostorového zobrazení objektů a informací i představení syntézy poznatků k některým vybraným tématům. Je členěna na dílčí sekce archeologické památky (2.1 - datové tř́ídy areály a objekty in situ), zaniklá architektura $(2.2$ - datová třída stavební projekty), hmotná kultura (2.3 - datová tř́ida vybraných pramenů, zčásti se předpokládá přejímání dat z jiných informačních systémů muzejní evidence) a Praha ve středověku (2.4 - datová tř́ída rekonstrukční areály). Tato datová třída je určena jak odborné veřejnosti a poučeným zájemcům o archeologii a historii, tak zčásti i veřejnosti nejširší. V sekci archeologických památek budou uvedeny významné archeologické nálezy, které dodnes spoluvytváří vzhled naší metropole a jsou v místě svého nálezu představeny často i běžným návštěvníkům Prahy. V této sekci předpokládáme kromě formalizovaných databázových údajů i možnost využití virtuálních prohlídek konkrétních míst či alespoň jejich představení standardní prezentací doprovázenou obrazovou či kresebnou dokumentací (celky, detaily, plány, rekonstrukce, historické prameny 


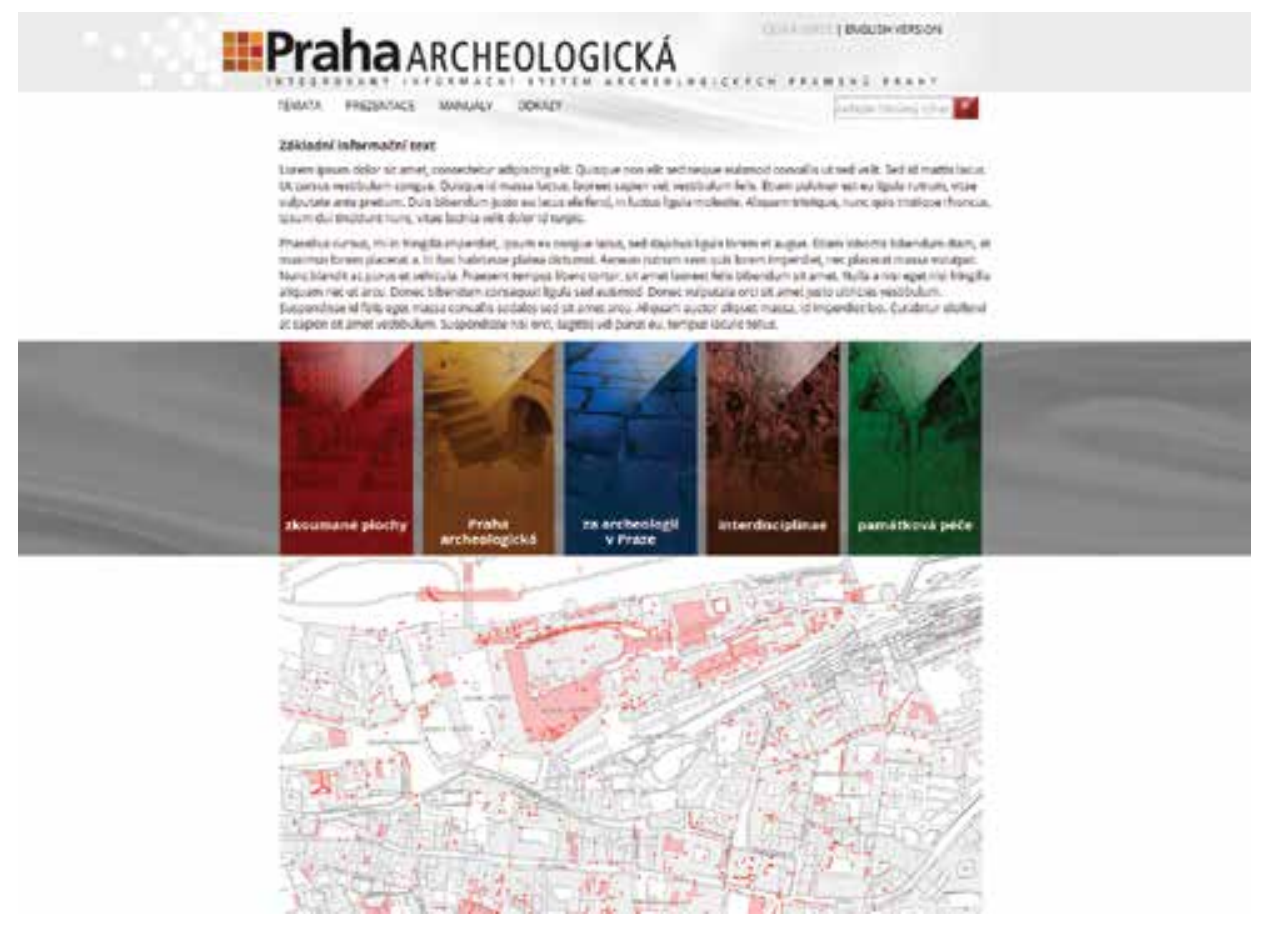

Obr. 5. Homepage projektu s ukázkou mapového zobrazení ADB. Styl zobrazení 1:1 000. Datový podklad (digitální katastrální mapa Prahy) (c) Institut plánování a rozvoje hl. m. Prahy.

Abb. 5. Homepage des Projekts mit einer Probe wie die archäologischen Dokumentationspunkte auf der Karte dargestellt werden. Darstellungsstil 1:1 000. Datenunterlage (digitale Katasterkarte von Prag) $\odot$ Institut für Planung und Entwicklung der Hauptstadt Prag.

atd.). Zájemci o detailnější informace budou mít pro jednotlivé areály k dispozici výčet nejvýznamnějších objektů, které jsou na daném místě prezentovány, přehled zastoupených materiálů či způsobů restaurování památek. Zaniklá architektura (datová třída stavební projekty) bude reprezentována zatím výběrově dvěma kategoriemi stavebních památek. Východiskem značně komplikovaného databázového záznamu, integrujícího poznatky různých historických oborů (archeologie, stavebně historického průzkumu, analýzy historických pramenů apod.), bude tzv. funkční celek. Je charakterizován definovaným stavebním typem jako interpretační nadčasovou kategorií a etapami jeho výstavby, kterými ve svém vývoji, at' již v podobě jedné konkrétní stavby, či jako soubor funkčně provázaných budov, procházel. Struktura databáze bude zahrnovat informace stavebně historického průzkumu, archeologické poznatky i archivní prameny a př́ípadné další typy analýz, evidovány budou i rozpoznatelné historické parcely a jejich vývoj, v případě existujících pramenů i vývoj historické funkce objektů. Prvou vloženou kategorií památek má být jeden z nejvýznamnějších fenoménů raně stř̌edověké Prahy, románské domy. Druhou prezentovanou kategorií je kategorie gotického měšt’anského domu. Ta bude představena alespoň ukázkově na dostupných př́kladech Nového Města pražského. V budoucnu by měla být tato sekce rozvíjena dle aktuálních poznatků a možností pražské archeologie. V sekci hmotné kultury, která by měla umožnit autorům výzkumů zpř́stupnit výjimečné či jinak zajímavé nálezy, se počítá zatím naopak s nesystematickým a spíše zcela náhodným výběrem významných či jinak pro veřejnost atraktivních movitých památek. Na druhé straně výsledky systematického studia témat klíčových pro poznání vývoje pražské sídlení aglomerace od jejích počátků v raném středověku až po zformování městského organismu by měly být postupně představovány v sekci označené jako Praha ve středověku. Tato sekce (datová tř́́da rekonstrukční areály) bude obsahovat a postupně představovat především formou mapového zobrazení a dílčích prezentací 


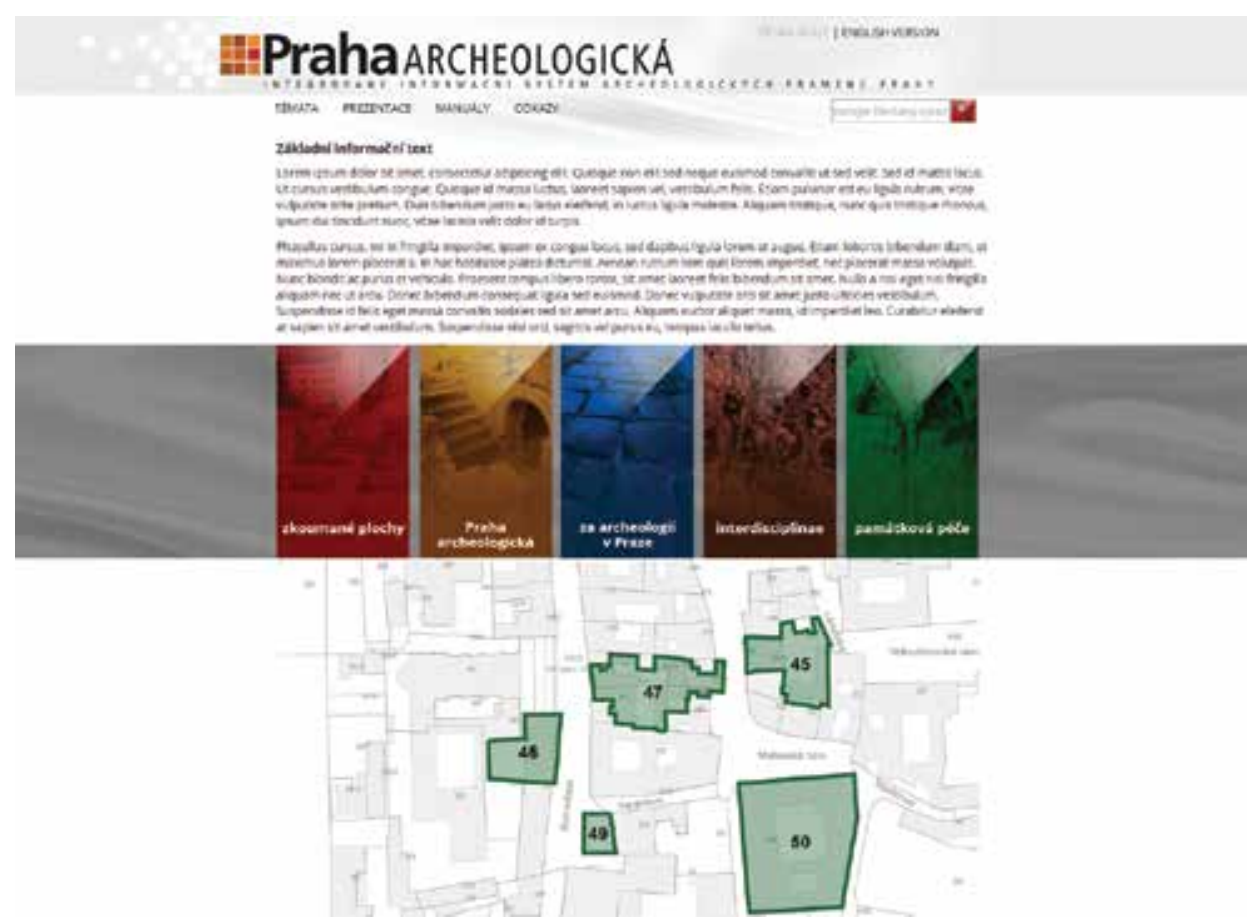

Obr. 6. Homepage projektu s ukázkou mapového zobrazení archeologicky významných ploch (přejatá data NPÚ). Styl zobrazení 1:1 000. Datový podklad (digitální katastrální mapa Prahy) $\odot$ Institut plánování a rozvoje hl. m. Prahy.

Abb. 6. Homepage des Projekts mit einer Probe wie archäologisch bedeutende Flächen auf der Karte dargestellt werden (vom Nationalinstitut für Denkmalpflege übernommene Daten). Darstellungsstil 1:1 000. Datenunterlage (digitale Katasterkarte von Prag) (C) Institut für Planung und Entwicklung der Hauptstadt Prag.

k vybraným otázkám aktuální stav poznání takových témat, jakými jsou opevnění Prahy a jeho vývoj, pohřební areály, pražské osady, zaniklá sakrální architektura, veřejná prostranství a komunikace apod. Sekce za archeologií v Praze (3 - datové tř́́dy procházky a objekty zájmu) je orientována na nejširší veřejnost. Tu chce přístupnou a atraktivní formou seznámit s výjimečným fondem pražské archeologie a zprostředkovat jí možnost navštívit a osobně poznat vybrané památky různého charakteru (dílčí archeologické nálezy in situ, sakrální i profánní architekturu, hradiště, některé technické památky), at' již v historickém jádru Prahy, či v jejím zázemí. Nenásilným způsobem by tak měl být vytvořen prostor pro popularizaci archeologie jako vědy, objasněna její úloha a význam pro poznání minulosti, vysvětleny principy záchrany archeologických pramenů, práce s nimi a objasněna i podstata dnešních záchranných archeologických výzkumů. Speciální položkou je sekce interdisciplinae (4 - datové třídy keramika, analýza a vzorek). Tato sekce si klade za cíl nejen umožnit systematický rozvoj a využíání interdisciplinárního výzkumu archeologických pramenů, ale také evidovat a zpř́istupnit informace o odběru a analýzách různých materiálových skupin či druhů objektů. V rámci IIS_APP bude možné nejen ve webovém prostředí doplňovat informace o nových prováděných analýzách a jejich typech, ale průběžně informovat i o jejich výsledcích, což samozřejmě systém MADB neumožňoval. Speciální, např. chronometrické, analýzy bude možné evidovat do úrovně jednotlivých vzorků, což umožní jak široké využití získaných unikátních dat, tak např̀ i posouzení oprávněnosti předložených interpretací. Součástí této sekce by měla být rovněž dlouhodobě postrádaná srovnávací databáze vybraných referenčních souborů keramiky z Prahy a jejího blízkého okolí, případně ve zdůvodněných př́ípadech i dalších lokalit. Poslední v řadě sekcí je sekce věnovaná památkové péči (co a jak je v Praze chráněno), jejímž úkolem je zprostředkování informací o skladbě a povaze památkového fondu a stupních jeho ochrany na území hlavního města. Cílena je především na 


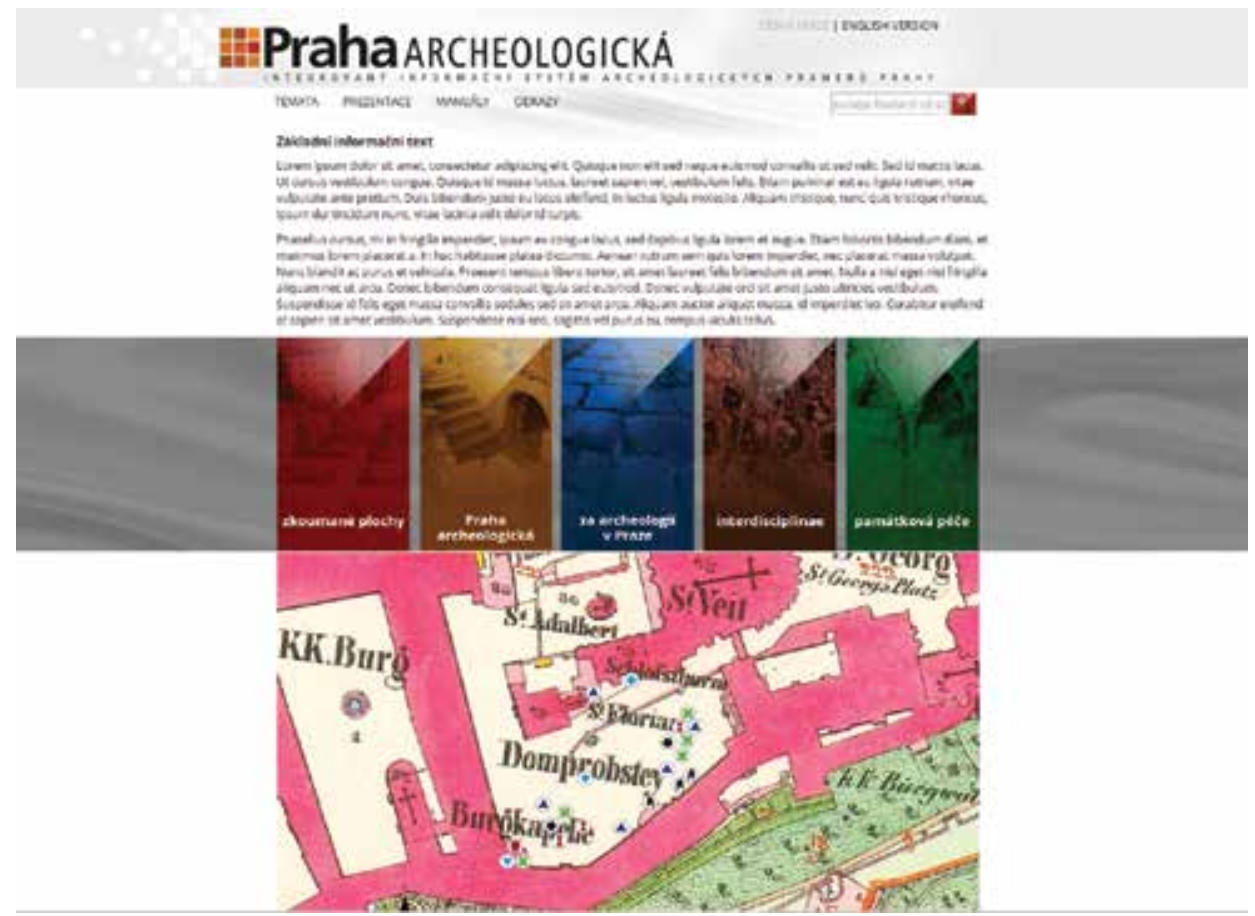

Obr. 7. Homepage projektu s ukázkou mapového zobrazení přehledu realizovaných analýz interdisciplinárního výzkumu. Styl zobrazení 1:1 000. Mapový podklad stabilní katastr ČUZK.

Abb. 7. Homepage des Projekts mit einer Probe wie die Übersicht der im Rahmen der interdisziplinären Untersuchung durchgeführten Analysen auf der Karte dargestellt werden. Darstellungsstil 1:1 000. Kartenvorlage stabiler Kataster des Tschechischen Instituts für Landesvermessung und Kataster.

prezentaci hodnot s archeologickým kontextem v centrální části města, jako jsou tzv. významné archeologické plochy na území Pražské památkové rezervace obsahující dosud výrazněji neponičené archeologické kontexty, př́ípadně v opačné poloze plochy, které již postrádají antropogenní nadloží, tedy místa s odstraněnou archeologickou vrstvou (sklepy, suterény novostaveb, podpovrchové dopravní stavby aj.). Doplňkem k údajům o povaze a stavu archeologických hodnot budou údaje o skladbě kulturních památek a památkově chráněných území. Data této sekce vychází nebo jsou př́mo přejímána z oborových databází vytvářených nebo spravovaných pracovišti Národního památkového ústavu prostřednictvím mapové služby.

Zatímco prostorové informace a data je provázející budou do systému v případě tříd nezávislých na MADB vstupovat vždy dávkově, prezentace $\mathrm{k}$ jakémukoliv z pojednávaných témat bude možné vkládat či aktualizovat v běžném redakčním systému on-line. Pražská archeologie tak získá možnost informovat o zcela aktuálním dění, nálezech či dalších atraktivních tématech. O procesu tvorby systému, jeho využitelnosti a prvých výsledcích bude průběžně informována odborná veřejnost na oborových konferencích a workshopech. Pro širokou veřejnost bude připravena publikace nabízející možnost osobního setkání s archeologickými památkami centra Prahy a jejího nejbližšího okolí. Pro závěrečnou fázi projektu (2016) je plánována konference, která bude věnována otázkám strategie a taktiky výzkumu městského organismu, metodám a metodice výzkumu, způsobům evidence i otázkám památkové ochrany a hospodaření s archeologickými prameny. Ne náhodou tato témata evokují názvy prací dr. L. Hrdličky, bez jehož vkladu by projekt IIS_APP nebyl realizovatelný a jehož přínos pro archeologii středověku si chceme touto konferencí a následným publikačním výstupem připomenout. 


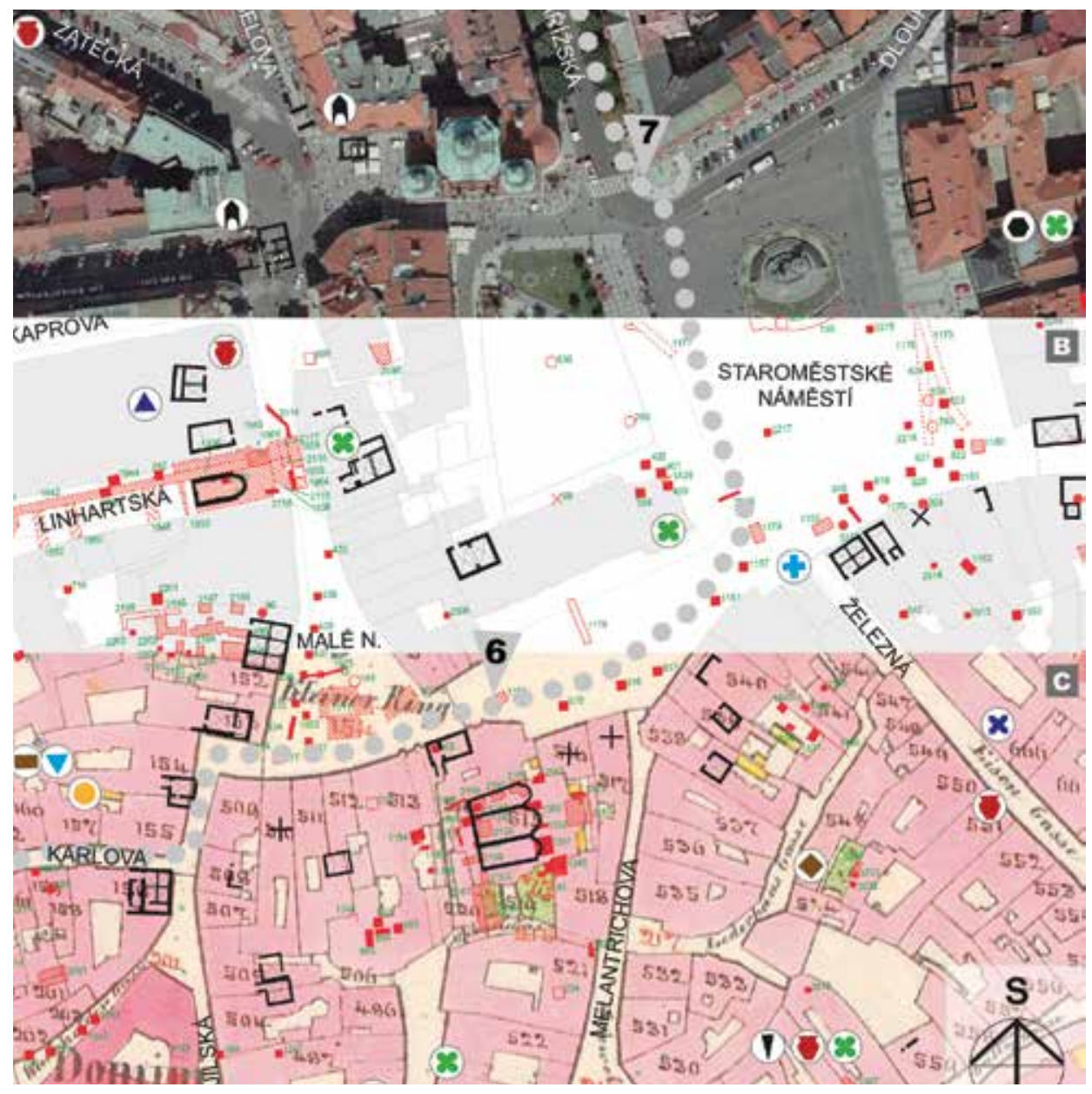

Obr. 8. Vícevrstevnaté zobrazení informací několika sekcí systému v různých mapových podkladech. Styl zobrazení 1:1 000. Datový podklad (digitální katastrální mapa Prahy) () Institut plánování a rozvojehl.m. Prahy. Mapový podklad stabilní katastr a ortofoto ČÚZK. Sestavila S. Babušková.

Abb. 8. Mehrschichtige Darstellung der Informationen von mehreren Systemteilen in verschiedenen Kartenvorlagen. Darstellungsstil 1:1 000. Datenunterlage (digitale Katasterkarte von Prag) (C) Institut für Planung und Entwicklung der Hauptstadt Prag. Kartenvorlage stabiler Kataster und Orthofoto des Tschechischen Instituts für Landesvermessung und Kataster. Zusammengestellt von S. Babušková.

\section{Závěr - vize pro budoucnost}

Pražská archeologie by v systému IIS_APP měla získat běžně dostupný a snadno využitelný nástroj, který by měl na jednom místě shromažd’ovat veškeré nezbyné informace pro vyhodnocování zkoumaných situací v potřebných souvislostech i řešení heuristicky a interpretačně složitých témat vývoje Prahy a její hmotné kultury. Dostupnost informací z celého sledovaného prostoru historického jádra Prahy může nejen umožnit jejich řešení z pohledu celé aglomerace, ale současně otevř́í řadu témat nových, a to i z oblasti mezioborového výzkumu. Pražský archeologický fond se svým $\mathrm{v}$ podstatě nevyčerpatelným potenciálem by se tak konečně mohl stát obecně přístupným a inspirativním zdrojem poznatků nejen o vývoji samotné metropole, ale i o vývoji městského organismu a jeho infrastruktury, rozmanitosti sociálního prostředí a technických dovedností, o vývoji technologií či využívání surovinových zdrojů, rozrůzněnosti 
hmotné kultury, distribuci, regionálních i nadregionálních kontaktech obecně. Neméně důležitou částí směřuící více do oblasti mimo vlastní obor jsou informace o památkových hodnotách pražského podzemního archivu a stávajících limitech, které jej mají chránit. V jejich zpřístupnění vidíme především nástroj preventivní povahy, umožňující předcházet nevhodným zásahům do organismu podzemí města a vést transparentní diskusi založenou na relevantních pramenech a informacích.

Výsledný informační systém by měl zajistit pražské archeologii rovněž maximální míru publicity a přesvědčit nejširší veřejnost o tom, že i v městském prostředí může být archeologie zdrojem unikátních poznatků, poutavých př́iběhů či informací o technických schopnostech a dovednostech našich předků, nebo dokonce o počátcích a hmotných projevech organizace státní moci či fungování městské samosprávy. V rámci mezioborového výzkumu může být inspirací z hlediska rozvoje metodiky či dokumentačních možností a někdy, např. v oblasti výzkumu lidských ostatků či výzkumu míst válečných událostí, přinést i odpovědi na zcela aktuální otázky společenské objednávky.

Společné budování systému institucemi, jakými jsou Archeologický ústav a Národní památkový ústav, a propojení IIS_APP se základním oborovým evidenčním systémem IS AMČR je zárukou funkčnosti IIS_APP i po ukončení projektu minimálně ve střednědobém výhledu. V každém př́ípadě již naplněním IIS_APP dostupnými daty v rámci pětiletého projektu budou informace o podstatné části již poznaného archeologického dědictví Prahy zpř́ístupněny odborné i široké veřejnosti, a ochráněny tak před možným znehodnocením či zapomenutím.

Text je dílčím výstupem projektu programu MK ČR NAKI reg. č. DF13P01OVV014.

\section{Literatura}

BOHÁČOVÁ, I., v tisku a: Archeologická památková péče v Praze v období první republiky, AR.

BOHÁČOVÁ, I., v tisku b: Prezentace torzální architektury v Čechách, AH 40.

ČULÍKOVÁ, V., v tisku: Archeobotanika - jeden z pramenů poznání pravěké, středověké a raně novověké Prahy. In: Praha archeologická.

DVORSKÁ, J.-BOHÁČOVÁ, I., 1999: Das historische Holz im Kontext der archäologischen Untersuchungen der Prager Burg. In: Probleme der mitteleuropäischen Dendrochronologie und naturwissenschaftliche Beiträge zur Talaue der March. Internationale Tagungen in Mikulčice 5 (Poláček, L.-Dvorská, J., edd.), 55-67. Brno.

HAVRDA, J.-PODLISKA, J.-ZAVŘEL, J., 2001: Surovinové zdroje, výroba a zpracování železa v raně středověké Praze (historie, současný stav a další perspektivy bádání) - Sources of raw materials, the production and working of iron in Early Medieval Prague (the history, present state and future perspectives of research), AR LII, 91-118.

HRDLIČKA, L., 2005: Praha. Podrobná mapa archeologických dokumentačních bodů na území Pražské památkové rezervace. Praha.

- 2009: Praha. Databáze podrobné mapy archeologických dokumentačních bodů na území městské památkové rezervace. (Aktualizace k 31. 12. 2005; e-Book). Praha.

KOZÁKOVÁ, R.-BOHÁČOVÁ, I., 2008: Přírodní prostředí Pražského hradu a jeho zázemí - výpověd’ pylové analýzy z raně středověkých sedimentů ze III. nádvoří - The natural environment of Prague Castle and its surroundings in the Early Middle Ages: Evidence provided by a pollen analysis of sediments from the Third courtyard, AR LX, 547-564.

PODLISKA, J., 2014: Eisenherstellung und -verarbeitung im frühmittelalterlichen Prag (Ein archäologischer Beitrag zur Erkenntnis nicht landwirtschaftlicher Aktivitäten im 9.-13. Jahrhundert. In: Tradition - Umgestaltung - Innovation. Transformationsprozesse im hohen Mittelalter (Gringmuth-Dallmer, Eike-Klápště, Jan-Hasil, Jan, edd.). Praehistorica XXXI, 707-727. Praha.

PODLISKA, J.-TRYML, M., 2012: Ochrana archeologických památek v Pražské památkové rezervaci, ZPP 72, 100-105.

RICHTER, M., 1984: Archeologický výzkum Prahy, Archaeologica Pragensia 5, 5-25.

RICHTER, M.-SMETÁNKA, Z., 1965: Archeologický výzkum středověké Prahy. In: Kniha o Praze, 297-305. Praha. 


\section{Zusammenfassung}

\section{Das archäologische Prag. Konzept und Realisierung des Projekts Integriertes Informations- system der archäologischen Quellen Prags (IIS_APP)}

Das Projekt Integriertes Informationssystem der archäologischen Quellen Prags basiert auf der Karte und der Datenbank der sich im Gebiet des Prager Denkmalschutzgebiets befindenden archäologischen Dokumentationspunkte (ADB), die 1975 im Archäologischen Institut Prag (heute Archäologisches Institut der Akademie der Wissenschaften der Tschechischen Republik, Prag) angelegt wurde. Das Konzept einer Karte und einer eigenen Datenbank stammt von PhDr. Ladislav Hrdlička (Hrdlička 2005; 2009). Das Projekt nutzt die neuen Informationstechnologien dazu, die ursprünglich physische Form der Karte in ein online aktualisiertes und öffentlich zugängliches GIS zu übertragen und die Angaben der Karte einerseits mit dem neu aufgebauten zentralen Informationssystem der tschechischen Archäologie (AMČR) und andererseits mit weiteren archäologischen bzw. für das Studium der Archäologie relevanten Quellen verknüpfen zu können. Das Projekt IIS_APP wird als allgemein nutzbares komplexes Informationssystem verstanden, das aufgrund der Kenntnisse breiterer Zusammenhänge die Wahl der angemessenen Grabungsmethode, eine qualifizierte fachliche sowie fachübergreifende Auswertung von archäologischen Quellen in den Innenbereichen historischer Siedlungen, einen wirtschaftlichen Umgang mit diesen Quellen und ihren qualifizierten und systematischen Schutz ermöglicht. Es ist auf alle potenziellen Benutzergruppen abgestimmt, d.h. auf die Fachöffentlichkeit (Grundlagenforschung einschließlich interdisziplinärer Themenbereiche, Denkmalpflege), auf die Organe der staatlichen Verwaltung und der örtlichen Selbstverwaltung sowie auf die breite Öffentlichkeit. Die Grundinhalte der Webpräsenz wurden den einzelnen Benutzergruppen angepasst. Das System geht von der Nutzung des relevanten, aktuell verfügbaren Karten- und Datenmaterials sowie von weiterem Material aus, das sich auf die Geschichte Prags oder auf Fragen des Denkmalschutzes beziehen und einerseits in den in das Projekt eingebundenen Institutionen (Archäologisches Institut Prag und Nationalinstitut für Denkmalpflege, Regionale Fachstelle in Prag) und außerhalb von diesen im Rahmen einer institutionsübergreifenden Zusammenarbeit generiert oder für eine online Nutzung allgemein verfügbar gemacht wurde (Institut für Planung und Entwicklung, Magistrat der Hauptstadt Prag, Stadtmuseum Prag, Archiv der Hauptstadt Prag, Historisches Institut der Akademie der Wissenschaften der Tschechischen Republik, Tschechisches Institut für Landesvermessung und Kataster u.a.). Die Realisierung des Projekts basiert auf den fachlichen Erfahrungen und auf der engen Zusammenarbeit zwischen den beiden größten Arbeitsstätten Tschechiens auf dem Gebiet der Archäologie (Archäologisches Institut der Akademie der Wissenschaften, Prag und Nationalinstitut für Denkmalpflege, Prag), die unter anderem sowohl Grundlagenforschung als auch archäologische Denkmalpflege betreiben. Dem Projektteam gehören außer auf Grundlagenforschung, Denkmalpflege und auf die Museumssphäre spezialisierte Archäologen auch Experten für die Bereiche Geologie, bauhistorische Analysen, Archäobotanik sowie Datenbanksysteme und GIS an. Die Verknüpfung zwischen dem Informationssystem Archäologische Karte der Tschechischen Republik und der institutionellen Zusammensetzung des Projektteams garantiert auch nach Projektende zumindest mittelfristig ein Funktionieren des IIS_APP. In jedem Fall werden die Informationen über einen wesentlichen Teil des bereits erforschten archäologischen Erbes Prags bereits durch das Füttern des IIS_APP mit den verfügbaren Daten während der Dauer des Projektes der Fachöffentlichkeit und auch einem breiten Publikum zugänglich gemacht und so auch vor einem möglichen Wertverlust bzw. vor dem Vergessen bewahrt.

Der vorliegende Beitrag ist Projektteilergebnis des Programms des Kulturministeriums der Tschechischen Republik Nationale und kulturelle Identität Reg.-Nr. DF13P01OVV014.

PhDr. Ivana Boháčová, Ph.D., Archeologický ústav AV ČR, Praha, v. v. i., Letenská 4, 11801 Praha 1, bohacova@arup.cas.cz

PhDr. Jaroslav Podliska, Ph.D., Národní památkový ústav, územní odborné pracoviště v hl. městě Praze, Na Perštýně 12/356, 11000 Praha 1 -Staré Město,podliska.jaroslav@npu.cz 
